TECHNICAL TRANSACTIONS 5/2017

CZASOPISMO TECHNICZNE 5/2017

MECHANICS

DOI: $10.4467 / 2353737 X C T .17 .079 .6436$

Tatiana Nikiforova (tatianaenik@mail.ru)

Food Products and Biotechnology Department, Organic Chemistry and Technology

Faculty, Ivanovo State University of Chemistry and Technology

\title{
Sergey Natareev
}

Machines and Equipment for Chemical Industry Department, Chemical Engineering

and Cybernetics Faculty, Ivanovo State University of Chemistry and Technology

\section{Vladimir Kozlov}

Chemistry and Technology of High Molecular Compounds Department, Organic

Chemistry and Technology Faculty, Ivanovo State University of Chemistry and Technology

\section{SPECIFIC FEATURES OF SORPTION KINETICS OF HEAVY METAL IONS WITH POLYSACCHARIDE MATERIALS FROM AQUEOUS MEDIA}

\section{CHARAKTERYSTYCZNE CECHY KINETYKI SORPCJI JONÓW METALI CIĘŻKICH Z MATERIAŁAMI POLISACHARYDOWYMI Z WODNYCH ŚRODOWISK}

\begin{abstract}
An investigation of sorption kinetics of heavy metal ions on polysaccharide materials has been performed. Traditionally, kinetic study of ion exchange sorption begins with a determination of the slowest stage of the proces, but the stage of chemical reaction between heavy metal ions and the sorbent functional groups can also make essential contribution. Results of kinetic studies were treated using different kinetic models and, experimental data are described most adequately with pseudo-second order kinetic model. It is determined that polysaccharide materials used in the studies have relatively good kinetic characteristics.
\end{abstract}

Keywords: biomaterials, polymers, adsorption, metals, surfaces

\section{Streszczenie}

Przeprowadzono badania kinetyki sorpcji jonów metali ciężkich na materiałach polisacharydowych. Tradycyjnie badanie kinetyczne sorpcji jonowymiennej rozpoczyna się od określenia najwolniejszego etapu procesu, ale stan reakcji chemicznej pomiędzy jonami metali ciężkich a sorbentowymi grupami funkcyjnymi może mieć również istotny udzial. Wyniki badań kinetycznych opisano różnymi modelami kinetycznymi, a najlepsze dopasowanie z danymi eksperymentalnymi uzyskano dla modelu kinetycznego reakcji pseudo drugiego rzędu. Ustalono, że materialy polisacharydowe stosowane w badaniach mają stosunkowo dobre właściwości kinetyczne.

Słowa kluczowe: biomateriały, polimery, adsorpcja, metale, powierzchnie 


\section{Introduction}

The perspective directions of the use of polymeric materials on the basis of cellulose is sorption of heavy metal ions from water solutions of various natures, including food systems, receiving pharmaceutical preparations and dietary supplements to food and also receiving metal nanoparticles immobilised on a polymeric matrix. Therefore, studying the regularities of metal ions sorption on cellulose- containing biopolymers arouses interest of researchers around the world.

To determine the mechanism of adsorption and rate-limiting stage of the process, including the mass transfer and chemical reaction, various kinetic models are used [1]. Advantageously, an ion exchange in a sorbent - water solution system, containing heavy metal ions, can be treated using the general theory of heterogeneous reactions, in accordance with which the process comprises five consecutive steps: 1) diffusion of heavy metal ions from the external solution throw a liquid film (film or external diffusion); 2) diffusion of heavy metal ions through the thickness of the resin grain to its active groups (internal or gel diffusion);3) chemical ion-exchange reaction; 4) diffusion of counterions displaced from the inner zone to the periphery of the resin grain (gel or internal diffusion); 5) the diffusion of counterions to solution phase through a liquid film (external diffusion).

The purpose of the experimental study of ion exchange kinetics is to identify the limiting, the rate-determining stage of the process. Stages 1 and 5, 2 and 4 are the same by diffusion nature and they are differ only in the direction of movement of exchanging ions and thus the treatment can be restricted with the first three of these stages (or with the latest three stages). The $3^{\text {rd }}$ stage characterises purely chemical kinetics, analytical expression, which is served by the following formula:

$$
-\frac{\partial C}{\partial \tau}=K\left(C_{\tau}-C_{e}\right)
$$

where $C_{\tau}$ and $C_{\mathrm{e}}$ - are the concentrations of heavy metal ion in solution, respectively, at time $\tau$ and after the establishment of equilibrium, $\mathrm{K}$ - is exchange constant.

It is well-known that the rate of the sorption process is modified by several parameters, such as the structural properties of the adsorbent (i.e. porosity, specific area, particle size, etc.), the properties of the metallic ions (ionic radius, number of coordination, and speciation), metallic ions concentration, chelates formation between metallic ions, and the adsorbent, etc. In practice, kinetic studies are performed using different initial concentrations of the adsorbate, adsorbent dosage, size of sorbent particles, mixing speeds, temperatures and $\mathrm{pH}$, as well as using various types of sorbates and sorbents. Then, linear regression can be used to determine the most appropriate kinetic equation. In the general case, the adsorption of metal ions increases with time until an equilibrium is established between the amount of sorbate present in the solution and in the sorbent. Typically, the adsorption reaction proceeds rapidly at the initial stage and is slowed down when approaching the equilibrium state. Equilibrium time varies for different sorbates, sorbents, and the initial concentration of the solution. 


\section{Theory}

To describe the adsorption process, different kinetic models are used, including pseudofirst and pseudo-second-order models, model of reversible reaction of the first order, the model of the external mass transfer and the Elovich model [1]. The most widely used models in the study of adsorption kinetics are the pseudo-first and especially the pseudo-second order kinetic models. Other kinetic models are used less frequently. Thus, it was found [2] that the experimental data on $\mathrm{Cr}(\mathrm{VI})$ ions biosorption by modified sawdust have been approximated by a reversible first-order reaction model. Ho and Mc Kay [3] have reported that most of the sorption systems followed a second-order kinetic model. It is important to note that a lot of data on sorption kinetics can be simultaneously well-described using different kinetic models; however, this does not mean that the experimental data do satisfy these models. Sometimes, sorption kinetics models can only be used for evaluation of the process. The most frequently used models are shown in Table $1[1,4]$.

Table 1. The most frequently used models of sorption kinetics

\begin{tabular}{|c|c|}
\hline Kinetic model & Integral form of equation \\
\hline pseudo-first order & $q_{t}=q_{e q}\left(1-e^{-k_{1} t}\right)$ \\
\hline pseudo-second order & $q_{t}=\frac{t}{\frac{1}{k_{2} \cdot q_{e q}^{2}}+\frac{1}{q_{e q}}}$ \\
\hline modified second order & $q_{t}=q_{e q}\left(1-\frac{1}{b+k_{2}^{\prime} t}\right)$ \\
\hline Elovich & $q_{t}=\frac{1}{\beta} \ln (1+\alpha \beta t)$ \\
\hline
\end{tabular}

where $\mathrm{q}_{\mathrm{eq}}$ and $\mathrm{q}$ - are the amounts of metal sorbed per unit weight of sorbent at equilibrium and at the time $\mathrm{t}$, respectively, $\mathrm{mg} / \mathrm{g}$;

$k_{1}$ - is the rate constant of pseudo-first-order sorption model, min $^{-1}$;

$k_{2}$ - is the rate constant of pseudo-second order sorption model, $\mathrm{g} \cdot \mathrm{mg}^{-1} \mathrm{~min}^{-1}$;

$k_{2}^{\prime}$ - is the rate constant of modified second-order sorption model, min $^{-1}$;

$b$ - is the parameter in modified second-order equation, $b \leq 1$;

$\alpha-$ is the initial rate of the sorption process, $\mathrm{g}^{\mathrm{mg}} \mathrm{m}^{-1} \cdot \mathrm{min}^{-1}$;

$\beta$-is the constant in Elovich equation, $\mathrm{g} \cdot \mathrm{mg}^{-1}$.

Effect of contact time on the adsorption of $\mathrm{Cu}$ (II) on shells of lentil (LS), wheat (WS) and rice (RS) are shown in Fig. 1 [5]. 


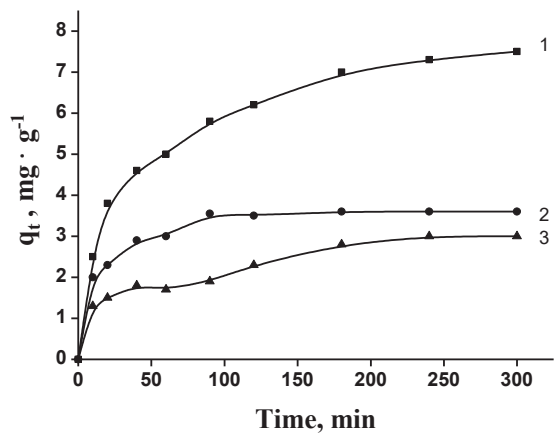

Fig. 1. Effect of contact time on the adsorption of $\mathrm{Cu}$ (II) on shells of lentil (1), wheat (2) and rice (3)

The first step in studying kinetics of ion exchange sorption is the determination of the slowest stage of the process. In purpose to elucidate the mechanism of the sorption process, the treatment of kinetic sorption curves of heavy metal ions by the equations of diffusion kinetics is used. It is known [6] that for the external diffusion process kinetic curve turns into a linear dependence in coordinates $-\lg (1-F)$ versus $t$, where $t$ - is time, $F$ - is the degree of achievement of equilibrium in the system, calculated as $F=q_{t} / q_{e q}$. If this condition is satisfied, it means that at a certain (often initial) time interval the diffusion in the film solution contributes to the overall rate of the process.

If plots of $F$ versus $t^{1 / 2}$ have initial linear part (at short contact times of phases), followed by a curved one, this indicates that the transport of metal ions in the sorbent grain controls the overall speed of the process [6]. Diffusion of ions through the solution film and diffusion in sorbent grain often makes a significant contribution to the overall speed of the process. In this case, the sorption of heavy metal ions takes place in the mixed diffusion mode.

In case of the formation of chelate complexes with metal ions on the sorbent during a sorption process a significant contribution to the kinetics of the ion exchange can also make the stage of chemical reaction between heavy metal ions and the sorbent functional groups. The next stage of the treatment of experimental kinetic data is the use of models to identify the contribution of the chemical stage. Such models include models of pseudo-first order, pseudo-second-order and modified second-order the Elovich model.

In order to determine the adsorption kinetics of $\mathrm{Cu}(\mathrm{II})$ ions, on selected cellulose biosorbents scientists [5] checked the first-order and the second-order kinetic models. The kinetic parameters were obtained by fitting data from experiments measuring the effect of contact time on adsorption capacity into pseudo-first and second-order equations.

The first-order rate expression of Lagergren based on solid capacity is generally expressed as follows:

$$
\lg \left(q_{e}-q_{t}\right)=\lg q_{e}-k t / 2,303
$$


where $q_{t}$ - is the amount adsorbed at time $\mathrm{t}, \mathrm{mg} / \mathrm{g}$;

$q_{e}$ - the amount of adsorbed ions at equilibrium, $\mathrm{mg} / \mathrm{g}$;

$k$ - the adsorption rate constant of adsorption, $\mathrm{min}^{-1}$.

The straight lines of the plot of $\log \left(q_{e}-q_{t}\right)$ versus time (Fig. 2) suggest the applicability of the Lagergren equation for the present system.

However, kinetic studies of biosorption from aqueous solutions of Cd(II) by fern [7], $\mathrm{Pb}$ (II) by a maize (Zea mays) stalk sponge [8], $\mathrm{Cu}$ (II) by peat and peanut shells modified with bicarbonate; $\mathrm{Cd}$ (II) by beech leaves and sugarcane; $\mathrm{Pb}$ (II) by cypress leaves [9], show that the most of experimental data are adequately described with the pseudo-second order kinetic model with high linearity coefficients. For example, the kinetics of $\mathrm{Pb}$ (II) sorption onto Zea mays biosorbent were well defined using linearity coefficients by the pseudosecond-order equation (0.9998).

The same conclusion was reached by the authors $[1,10]$ based on an analysis of publications on the heavy metal ions sorption by polysaccharide biosorbents. The authors [5] also used the pseudo-second-order kinetics model to describe the sorption of copper ions by shells of lentils, wheat and rice.

$$
t / q_{t}=1 / k q_{e}^{2}+1 / q_{e}
$$

where $k$ - is the adsorption rate constant, $\mathrm{g} \cdot \mathrm{mg}^{-1} \cdot \mathrm{min}^{-1}$.

A plot of $t / q_{t}$ versus time, shown in Fig. 3 shows that obtained kinetic data are also well described by the pseudo-second order kinetics model.

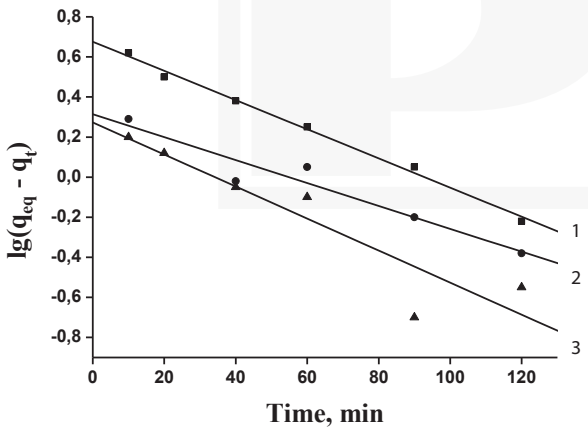

Fig. 2. Pseudo first-order sorption kinetics of $\mathrm{Cu}$ (II) on shells of lentil (1), wheat (2) and rice (3)

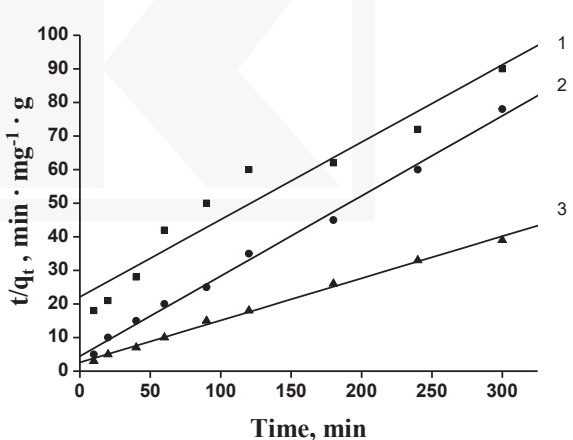

Fig. 3. Pseudo second-order sorption kinetics of $\mathrm{Cu}(\mathrm{II})$ on shells of lentil (1), wheat (2) and rice (3)

The plots of $\mathrm{q}_{\mathrm{t}}$ versus $\mathrm{t}^{1 / 2}$ for different adsorbents have a similar general trend and initial curved part, followed by a linear one and then a plateau. The initial curved part may be attributed to the bulk diffusion; the linear one to the intraparticle diffusion and the plateau 
to the equilibrium. This indicates that the transport of $\mathrm{Cu}$ (II) ions from the solution through the particle solution interface into the pores of the particles as well as the adsorption on the available surface of adsorbents are both responsible for the uptake of $\mathrm{Cu}$ (II) ions [5].

It is necessary to note that the pseudo-first order kinetic equation is identical to the equation for the film kinetics. However, in the case of film diffusion, the rate of sorption process depends on the size of the sorbent particles and the film thickness. If the rate-limiting step is chemical reaction, then the rate of sorption process does not dependent on these factors and it depends only on the ion concentration and temperature. Thus, in the case when sorption process is described by the pseudo-first order kinetics model, the diffusion takes place before sorption.

Both of the pseudo-first order and the pseudo-second-order model assume that a chemical reaction is the limiting stage of the sorption process. In this case, it is assumed that the reaction between the sorbate and the sorbent functional group is a second-order reaction, and they interact with each other as $1: 1[9,11]$.

Based on the data presented in the literature, it can be concluded that despite the use of various models, the pseudo-second-order kinetic model the most correctly describes the kinetics of sorption process of heavy metal ions on cellulose containing biopolymer sorbents (Table 2).

Table 2. Kinetic models used in processing the kinetic data for the sorption of heavy metals on cellulose containing biosorbents

\begin{tabular}{|c|c|c|c|c|c|}
\hline \multirow{2}{*}{$\begin{array}{c}\text { Cellulosic } \\
\text { biosorbents }\end{array}$} & \multirow{2}{*}{$\begin{array}{l}\text { Heavy metal } \\
\text { ions }\end{array}$} & \multicolumn{2}{|c|}{ Sorption capacity, } & \multirow{2}{*}{$\begin{array}{c}\text { Kinetic } \\
\text { model }\end{array}$} & \multirow{2}{*}{ References } \\
\hline & & $\mathrm{mg} \cdot \mathrm{g}^{-1}$ & mmole.g ${ }^{-1}$ & & \\
\hline Oak sawdust & $\begin{array}{l}\mathrm{Cu}(\mathrm{II}) \\
\mathrm{Ni}(\mathrm{II})\end{array}$ & $\begin{array}{l}3.2 \\
3.5\end{array}$ & $\begin{array}{l}0.05 \\
0.06\end{array}$ & $\begin{array}{c}\text { pseudo- } \\
\text { second-order }\end{array}$ & {$[12]$} \\
\hline Neem biomass & $\mathrm{Zn}(\mathrm{II})$ & 13.7 & 2.1 & second-order & {$[13]$} \\
\hline Rosewood & $\mathrm{Cr}(\mathrm{VI})$ & 15.1 & 0.29 & first-order & {$[14]$} \\
\hline Cassia & $\mathrm{Ni}(\mathrm{II})$ & $19.7-168.2$ & $0.34-2.9$ & second-order & {$[15]$} \\
\hline Papaya & $\begin{array}{l}\mathrm{Cu}(\mathrm{II}) ; \\
\mathrm{Cd}(\mathrm{II}) ; \\
\mathrm{Zn}(\mathrm{II})\end{array}$ & - & - & second-order & {$[16]$} \\
\hline Juniper & $\mathrm{Cd}(\mathrm{II})$ & 9 & 0.08 & $\begin{array}{c}\text { pseudo- } \\
\text { second-order }\end{array}$ & {$[17]$} \\
\hline Newsprint & $\mathrm{Cu}(\mathrm{II})$ & 30 & 0.47 & second-order & {$[18]$} \\
\hline Corn stalks & $\mathrm{Cd}(\mathrm{II})$ & 3.4 & 0.03 & $\begin{array}{c}\text { pseudo- } \\
\text { second-order }\end{array}$ & [19] \\
\hline Eucalyptus & $\begin{array}{l}\mathrm{Cd}(\mathrm{II}) \\
\mathrm{Hg}(\mathrm{II})\end{array}$ & $\begin{array}{c}18 \\
32.1\end{array}$ & $\begin{array}{l}0.16 \\
0.16\end{array}$ & $\begin{array}{c}\text { pseudo- } \\
\text { second-order }\end{array}$ & {$[20,21]$} \\
\hline Guava & $\mathrm{Hg}(\mathrm{II})$ & 3.2 & 0.016 & second-order & {$[22]$} \\
\hline Teak leaves & $\begin{array}{l}\mathrm{Cu}(\mathrm{II}) \\
\mathrm{Cd}(\mathrm{II})\end{array}$ & $\begin{array}{c}96 \\
168\end{array}$ & $\begin{array}{l}1.5 \\
1.5\end{array}$ & $\begin{array}{c}\text { pseudo- } \\
\text { second-order }\end{array}$ & {$[23]$} \\
\hline Hevea leaves & $\mathrm{Cu}(\mathrm{II})$ & $\begin{array}{c}9- \\
15.2\end{array}$ & $0.14-0.24$ & $\begin{array}{c}\text { pseudo- } \\
\text { second-order }\end{array}$ & {$[24]$} \\
\hline
\end{tabular}




\begin{tabular}{|c|c|c|c|c|c|}
\hline Ficus & $\begin{array}{l}\mathrm{Pb}(\mathrm{II}) \\
\mathrm{Cr}(\mathrm{VI})\end{array}$ & $\begin{array}{c}166 \\
6.2\end{array}$ & $\begin{array}{c}0.08 ; \\
0.12\end{array}$ & $\begin{array}{c}\text { pseudo- } \\
\text { second-order }\end{array}$ & {$[25]$} \\
\hline Thuja & $\mathrm{Ni}(\mathrm{II})$ & - & - & $\begin{array}{c}\text { pseudo- } \\
\text { second-order }\end{array}$ & {$[26]$} \\
\hline Hazelnut shells & $\begin{array}{l}\mathrm{Ni}(\mathrm{II}) \\
\mathrm{Cd}(\mathrm{II}) \\
\mathrm{Pb}(\mathrm{II})\end{array}$ & $\begin{array}{l}1.8 \\
3.4 \\
4.1\end{array}$ & $\begin{array}{l}0.03 \\
0.03 \\
0.02\end{array}$ & $\begin{array}{c}\text { pseudo- } \\
\text { second-order }\end{array}$ & {$[27]$} \\
\hline Acorns & $\mathrm{Cr}(\mathrm{VI})$ & 31 & 0.60 & $\begin{array}{c}\text { pseudo- } \\
\text { second-order }\end{array}$ & [28] \\
\hline Coco copra & $\mathrm{Cd}(\mathrm{II})$ & 1.7 & 0.015 & $\begin{array}{c}\text { pseudo- } \\
\text { second-order }\end{array}$ & [29] \\
\hline $\begin{array}{c}\text { Fibres of } \\
\text { a coconut palm } \\
\text { tree }\end{array}$ & $\begin{array}{l}\mathrm{Co}(\mathrm{II}) \\
\mathrm{Cr}(\mathrm{III}) \\
\mathrm{Ni}(\mathrm{II})\end{array}$ & $\begin{array}{c}13 \\
12 \\
15.7\end{array}$ & $\begin{array}{l}0.22 \\
0.23 \\
0.27\end{array}$ & $\begin{array}{c}\text { pseudo- } \\
\text { second-order }\end{array}$ & {$[30]$} \\
\hline Peel of beans & $\mathrm{Cd}(\mathrm{II})$ & 36 & 0.32 & $\begin{array}{c}\text { pseudo- } \\
\text { second-order }\end{array}$ & {$[31]$} \\
\hline Rice husk & $\mathrm{Cd}(\mathrm{II})$ & 9 & 0.08 & $\begin{array}{c}\text { pseudo- } \\
\text { second-order }\end{array}$ & {$[32]$} \\
\hline Sugar beet & $\mathrm{Cu}(\mathrm{II})$ & 55.7 & 0.87 & $\begin{array}{c}\text { pseudo- } \\
\text { second-order }\end{array}$ & {$[33]$} \\
\hline Olive stone & $\begin{array}{l}\mathrm{Pb}(\mathrm{II}) \\
\mathrm{Ni}(\mathrm{II}) \\
\mathrm{Cu}(\mathrm{II}) \\
\mathrm{Cd}(\mathrm{II})\end{array}$ & $\begin{array}{l}8.3 \\
1.7 \\
1.9 \\
7.9\end{array}$ & $\begin{array}{l}0.04 \\
0.03 \\
0.03 \\
0.07\end{array}$ & $\begin{array}{c}\text { pseudo- } \\
\text { second-order }\end{array}$ & {$[34]$} \\
\hline
\end{tabular}

\section{Materials and methods}

\subsection{Materials}

Cotton cellulose. Cellulose content absolutely dry cotton fibres is approximately $95 \%$. The main impurities - waxy, protein, pectins, hemicellulose, mineral salts, and natural dyes, which are mainly concentrated in the primary side of the channel and cotton fibre [35]. Cellulose is one of the most widespread natural polymers, the main component of plant cell walls, for the mechanical strength and elasticity of plant tissues. Cellulose macromolecules are built from elementary units of $\mathrm{D}$-glucose (in the pyranose form) connected $1,4-\beta-$ glycosidic bonds in linear unbranched chains:

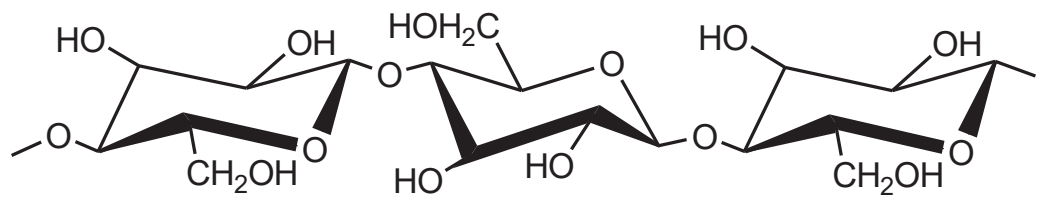


For $\beta$-D-glucopyranose and its derivatives (including for cellulose) energetically most favourable shape is the $\mathrm{C} 1$ chair conformation wherein all of the hydroxyl groups are in the equatorial position, i.e. in the plane of the ring [36].

Short flax fibre is a secondary product of processing of linen industry of following composition, \%: (cellulose (75-78), hemicellulose (9.4-11.9), lignin (3.8), pectin (2,9-, 2), waxy substance (2.7), nitrogen-containing substances based on proteins (1.9-2.1), mineral substances $(1.3-2.8)$ [37].

Production of textile materials based on flax fibres is accompanied by increased waste production of flax: short fibres and lignified stems of flax (bonfires), which can serve as raw materials for efficient and environmentally friendly sorbents. However, waste resulting from the processing of flax, only partly used in the industry (tow, cleaning material), and linen fire is almost completely burnt [38].

Wood pine sawdust - is a wood industry waste (composition, \% of absolutely dry wood) cellulose - 53.8\%; hemicellulose - 20.5\%; lignin - 26.9-28.2\%; pentosans - 10.7-11.2\%; mannan $-7.1 \%$; galactan $-1.5 \%$; ash $-0.2-0.23 \%$; extractives $-2.0 \%$ [39].

The stems of artichoke is an agricultural waste of the following composition: $25-28 \%$ cellulose, $19-21 \%$ inulin, $8-10 \%$ pectin, $7-8 \%$ hemicellulose, 3\% starch, $14-17 \%$ lignin, $7 \%$ organic acids $4-6 \%$ protein, $2.4-2.6 \%$ minerals, $1.3 \%$ fat, $0.6-1.2 \%$ of waxy substances, $7.9 \%$ water [40]. Amorphous cellulose obtained from artichoke stems core was used as a sorbent.

Wheat bran of the following composition: starch and dextrin -23.5 ; cellulose -20 ; pectin - 12; hemicellulose - 6.3; protein - 15.1; ash - 4.9; fats - 3.8; water - 14,4\% [ 41 ]

Soybean meal is produced as industrial waste after the extraction of oil from soy seeds by pressing and extraction, and comprise a mixture of cellulose (14\%) and protein (45\%) and up to $4 \%$ of fat [42].

Soy flour of the following composition: proteins $-43-48 \%, 12-14$ sugar, dextrin $-8 \%$, minerals $-6-8 \%$, fat $-8.5 \%$ fibre $-5-7 \%$.

As a source of metal ions were used $\mathrm{CuSO}_{4} \cdot 5 \mathrm{H}_{2} \mathrm{O} \quad \mathrm{NiSO}_{4} \cdot 7 \mathrm{H}_{2} \mathrm{O} \quad \mathrm{ZnSO}_{4} \cdot 7 \mathrm{H}_{2} \mathrm{O}$; polysaccharide materials have been treated using $\mathrm{NaHCO}_{3}$ and $\mathrm{NaOH}$. All reagents were of "chemically pure" grade.

\subsection{Determination of the carboxyl groups content in polysaccharide materials by the method of potentiometric titration}

The number of carboxyl groups in cellulose materials was determined using the classical method based on interaction of acidic groups with calcium acetate and titrimetric determination of the formed acetic acid [43, 44]. Its content per unit of the sorbent mass is assumed to be the carboxyl acidity: 


$$
[-\mathrm{COOH}]=\frac{V_{\mathrm{NaOH}} \cdot \mathrm{C}_{\mathrm{NaOH}}}{m}
$$

where:

$V_{\mathrm{NaOH}}-$ is the volume of $\mathrm{NaOH}$ used in titration, $\mathrm{ml}$;

$\mathrm{C}_{\mathrm{NaOH}}$ - is the concentration of the $\mathrm{NaOH}$ solution, mol. $\mathrm{r}^{-1}$;

$m$ - is the sorbent mass, $\mathrm{g}$.

\subsection{Determination of the specific surface area, pore volume, pore size distribution of the polysaccharide materials by adsorption - desorption of nitrogen}

The specific surface $S_{s p}$, total pore volume and pore size distribution of polysaccharide materials were determined by nitrogen adsorption at $77 \mathrm{~K}$ using automated sorption installation Quantochrome NOVA 1200e, USA by the method of Brunauer, Emmett, Teller (BET). Preparation of samples for the study was carried out by degassing of the polymer material under vacuum for 3 hours at $60^{\circ} \mathrm{C}$ [45]. Taking into account that the size of the specific surface area of cellulosic material in a dry state is small [46], samples of 0.5-1.0 $\mathrm{g}$ were used. Samples were placed in special glass tubes and were heated with simultaneous degassing. Nitrogen adsorption isotherms were received.

Specific surface area $\left(S_{s p}\right)$ is calculated by low-temperature vapour sorption isotherm of nitrogen as follows:

$$
S_{y d}=S_{0} \cdot A_{\infty} \cdot N_{A}
$$

where: $A_{\infty}$ - is the maximum sorption capacity of the polysaccharide material; $N_{\mathrm{A}}-$

Avogadro's number; $S_{0}$ - the area occupied by one molecule of gas in the adsorption layer.

For hexagonal dense monolayer of nitrogen at $77 \mathrm{~K}$ the cross-sectional area $S_{0}$ for nitrogen is $16,2 \AA^{2}$.

\subsection{Kinetics of heavy metal ions sorption on cellulose-based biopolymers}

The study of heavy metal ions sorption was carried out under static conditions from aqueous solutions of metal sulphates with stirring and temperature control at $293 \mathrm{~K}$.

Sorption kinetics were investigated by the limited solution volume method [47]. To obtain the kinetic sorption curves, samples of sorbent $(m)$ of $0.1 \mathrm{~g}$ were placed in several flasks, filled with $10 \mathrm{ml}(\mathrm{V})$ aqueous solution of metal sulphate and kept from $5 \mathrm{~min}$ to $24 \mathrm{~h}$. The initial concentration $\left(C_{0}\right)$ of metal ions was $1.5 \cdot 10^{-4} \mathrm{~mol} \cdot \mathrm{l}^{-1}$. The solution was separated 
from the sorbent by filtration at regular intervals, the current concentration of metal ions $\left(C_{\tau}\right)$ being determined using apparatus "Saturn" by atomic absorption spectroscopy.

Sorption capacity $\left(A_{\tau}\right)$ of sorbents at any given time was calculated by the formula:

$$
A_{\tau}=\frac{\left(C_{0}-C_{\tau}\right)}{m} \cdot V
$$

At equilibrium, the equilibrium concentration of metal ions in solution $\left(C_{\mathrm{e}}\right)$ was determined and the equilibrium sorption capacity of biosorbents $(A)$ was calculated:

$$
A=\frac{\left(C_{0}-C_{e}\right)}{m} \cdot V
$$

Sorption degree $\alpha$ was determined as follows:

$$
\alpha=\frac{C_{0}-C}{C_{0}} \cdot 100 \%
$$

The degree of the sorption process completeness $(F)$ was determined as follows:

$$
F=\frac{A_{\tau}}{A}
$$

The distribution coefficient of heavy metal ions $\left(K_{D}\right)$ between the solution phase and the phase of polysaccharide material was determined as the ratio of the concentration of metal ions in the sorbent phase to the concentration of metal ions in solution at equilibrium:

$$
K_{D}=\frac{A}{C_{e}}
$$

\subsection{Determination of swelling of polymeric materials}

The degree of swelling was determined by the gravimetric method [48]. $10 \mathrm{ml}$ of distilled water was added to the dried sample of the polymer material and the mixture was incubated at room temperature with periodic stirring for 48 hours. Then, the swollen sample was transferred onto a glass filter, the solvent was removed under vacuum (water-jet pump for 5 minutes) and the sample was weighed. The degree of swelling $\mathrm{X}\left(\mathrm{g} \cdot \mathrm{g}^{-1}\right)$ of polymer material is given by:

$$
\mathrm{X}=\left(m_{s w}-m_{d r}\right) / m_{d r}
$$

where $m_{s w}$-is the mass of the swollen polysaccharide material;

$m_{d r}$ - the mass of the dried polysaccharide material.

\subsection{Pretreatment of polysaccharide materials}

Cotton cellulose was boiled in $5 \% \mathrm{NaHCO}_{3}$ solution for $30 \mathrm{~min}$, then drained, washed repeatedly with distilled water up to neutral $\mathrm{pH}$ and dried in an oven at $110^{\circ} \mathrm{C}$ to constant weight. Air-dried samples had moisture content of $8 \%$. 
Artichoke stems previously purified from the outer layer (epidermis, cork, bark, phloem), then white spongy core was dried, crushed and sieved through a sieve with a hole diameter of 300 microns. The samples used were air dried to 6-8\% humidity;

Polysaccharide material, such as pine sawdust, wheat bran, soybean meal dried in an oven to constant weight and ground. The crushed materials and soy flour was sieved through a sieve with a hole diameter of 300 microns.

\section{Results and discussion}

\subsection{Evaluation of the sorption capacity of polysaccharide materials based on carboxyl group content}

To evaluate the sorption capacity of polysaccharide materials, it is necessary to determine the content of sorption-active groups. In cellulose sorbents, sorption-active groups are mainly the carboxyl groups. Carboxyl groups can exist in cellulose as a terminal and side groups at 2, 3 and 6 carbon atoms. This produces $\alpha$-hydroxycarboxylic acid, containing-OH groups in the a-position: $\mathrm{R}-\mathrm{CH}(\mathrm{OH}) \mathrm{COOH}$.

The $\mathrm{pK}_{\mathrm{a}}$ values of acidic groups of cellulose $\left(\mathrm{pK}_{\mathrm{a}(\mathrm{COOH})} 3,7-3,9\right)$ :
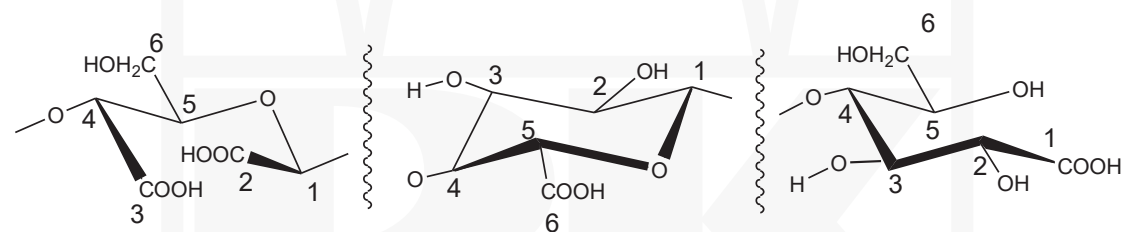

\section{Cell- $\mathrm{CH}(\mathrm{OH})-\mathrm{COOH} \leftrightarrow$ Cell- $\mathrm{CH}(\mathrm{OH})-\mathrm{COO}^{-}+\mathrm{H}^{+}$}

are in a good agreement with $\mathrm{pK}_{\mathrm{a}}$ of carbonic acids having OH-group in $\alpha$-position $\left(\mathrm{pK}_{\mathrm{a}(\mathrm{COOH})} 3,71-3,83\right)[49]$, and also with literature data for cellulose containing materials $\left(\mathrm{pK}_{\mathrm{a}(\mathrm{COOH})} 4,0\right)[44]$.

Thus, mechanism of heavy metal ions sorption on cellulose biosorbents is the ion exchange mechanism on carboxylic groups, and biosorbents are the cationites in $\mathrm{H}$ - or $\mathrm{Na}$ - form:

$$
\text { 2Cell- } \mathrm{CH}(\mathrm{OH})-\mathrm{COOH}+\mathrm{M}^{2+} \leftrightarrow \text { Cell- }(\mathrm{CH}(\mathrm{OH})-\mathrm{COO})_{2} \mathrm{M}+2 \mathrm{H}^{+}
$$

Curves of potentiometric titration in integral and differential forms for the sorbent from artichoke stems are shown in Fig. 4 and 5.

The content of $-\mathrm{COOH}$ groups in the polysaccharide material from artichoke stems was determined according to formula (4). 
The value of the sorbent carboxylic acidity was $0.82 \mathrm{~m}$-eq. $\mathrm{g}^{-1}$. The polysaccharide material from artichoke stems has the highest content of carboxyl groups among all considered polysaccharide materials. Thus, the content of - $\mathrm{COOH}$ groups in the flax fibres and wood pulp, respectively, is $0.46 \mathrm{~m}$-eq.g ${ }^{-1}$ and $0.34 \mathrm{~m}$-eq. $\mathrm{g}^{-1}$.

The elemental composition of the biopolymer sorbent determined using Flash EA 1112 analyser $(\mathrm{C}-41.1 \% ; \mathrm{H}-6.1 \%)$ indicates its polysaccharide nature $\left(-\mathrm{C}_{6} \mathrm{H}_{10} \mathrm{O}_{5}-\right)_{\mathrm{n}}$.

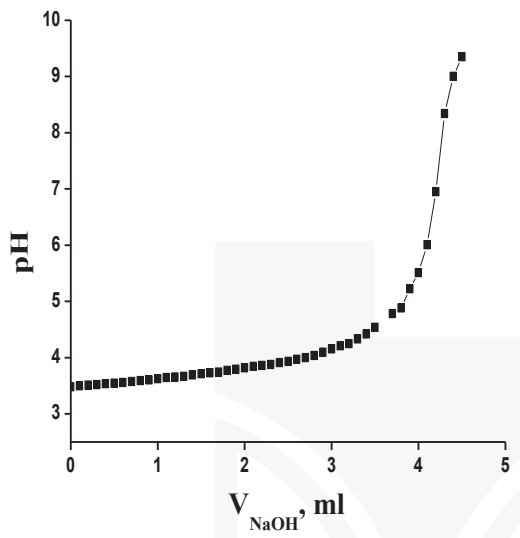

Fig. 4. Determination of the carboxyl groups content in the polysaccharide material from artichoke stems

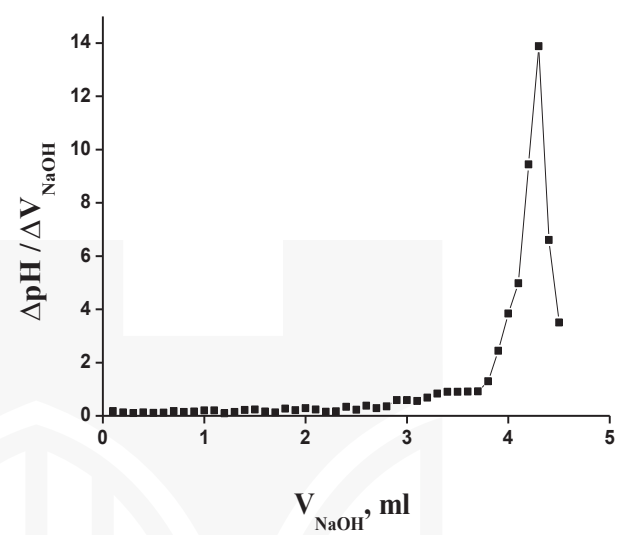

Fig. 5. Differential titration curve of polysaccharide material from artichoke stems

\subsection{Study of polysaccharide materials by the method of adsorption - desorption of nitrogen}

Study of polysaccharide biosorbents by the method of adsorption - desorption of nitrogen allows to determine the specific surface, the average pore diameter and total pore volume (instrument Quantochrome NOVA 1200e, nitrogen adsorption proceeds at $77 \mathrm{~K}$ ). The adsorption - desorption isotherms on the polysaccharide sorbent from artichoke stems, as well as pore size distribution in integral and differential form are presented in Fig. 6-8.

Comparing the obtained values of specific surface area $\left(S_{s p}\right)$, the pore volume $(V)$ and pore diameter $(D)$ for cellulose, core artichoke stems, flax fibres with literature data for a number of cellulosic materials is shown in Table 3.

When comparing obtained $S_{s p}$ values for investigated polysaccharide sorbents with a surface area of a number of secondary agriculture products (wheat straw $-10 \mathrm{~m}^{2} \cdot \mathrm{g}^{-1}$, buckwheat hulls $-11 \mathrm{~m}^{2} \cdot \mathrm{g}^{-1}$, sunflower husks $-20 \mathrm{~m}^{2} \cdot \mathrm{g}^{-1}$ ) [50], it is possible to conclude that the investigated polysaccharide materials have rather developed surface for cellulosecontaining materials. Smaller pore volume compared with the literature data is due to the use of different methods for determining, and it is defined for pores with a diameter less than $180.5 \mathrm{~nm}$. The values of the pore diameter of cellulose materials coincide with the data [35] and evidence about their microporous structure. 


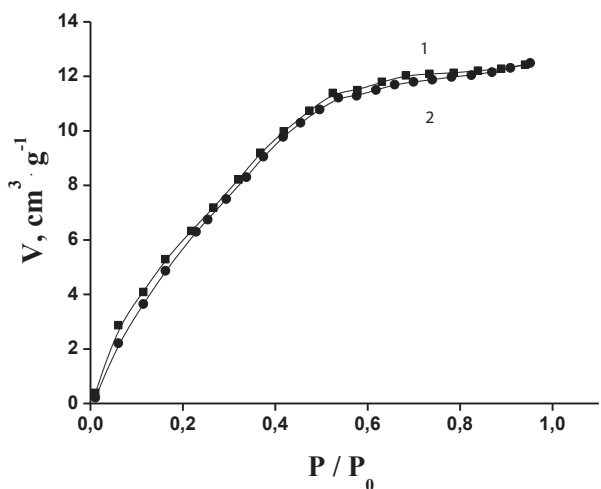

Fig. 6. The adsorption (1) - desorption (2) isotherms on the polysaccharide sorbent from artichoke stems

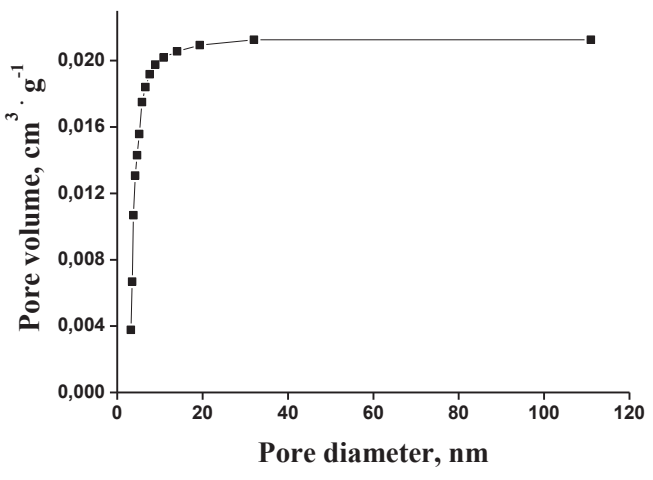

Fig. 7. Integral curve of pore size distribution

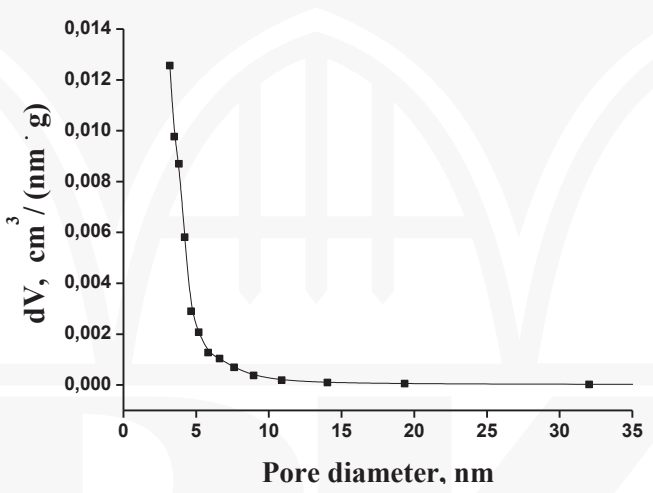

Fig. 8. Differential curve of pore size distribution

Table 3. Characteristics of cellulose-containing materials

\begin{tabular}{|c|c|c|c|c|c|}
\hline \multirow{2}{*}{ Parameter } & \multicolumn{4}{|c|}{ Material } \\
\cline { 2 - 6 } & \multicolumn{3}{|c|}{ Experimental data } & \multicolumn{2}{c|}{ Literature data } \\
\cline { 2 - 6 } & cellulose & artichoke stems & flax fibres & $\begin{array}{c}\text { sunflower } \\
\text { husks }\end{array}$ \\
\hline $\mathrm{S}_{\mathrm{sp}} \mathrm{m}^{2} \cdot \mathrm{g}^{-1}$ & 36,5 & 29,3 & 15,9 & 13 & 37 \\
$\mathrm{~V}, \mathrm{~cm}^{3} \cdot \mathrm{g}^{-1}$ & & & & & \\
determined & & 0,015 & 0,009 & & \\
with $\mathrm{N}_{2}$ & 0,018 & & & 0,10 & 0,09 \\
with $\mathrm{C}_{6} \mathrm{H}_{6}$ & & & & 0,22 & 0,20 \\
with $\mathrm{CH}_{3} \mathrm{OH}$ & & & 3 & 0,24 & 0,19 \\
with $\mathrm{H}_{2} \mathrm{O}$ & & 2 & & - & - \\
$\mathrm{D}, \mathrm{nm}^{*}$ & 3 & & & & \\
\hline
\end{tabular}




\subsection{The kinetics of sorption of heavy metal ions on cellulose-containing biopolymer materials}

Kinetic studies were performed to determine the equilibrium time at distribution of heavy metal ions in heterophase system "polysaccharide material - the aqueous metal salt solution", as well to determine the influence of mixing on the sorption process and to establish the limiting stage of the process. Kinetic curves of metal ions sorption on polysaccharide sorbents were treated using pseudo-first and pseudo-second order kinetic models.

To determine the equilibrium sorption time in the heterophase system "aqueous solution of zinc sulphate - sorbent" kinetic curves were obtained for sorption of $\mathrm{Zn}$ (II) on wheat bran and soybean meal. As it is shown in Fig. 9, the equilibrium at distribution of zinc ions without agitation is reached relatively slowly - for $2 \mathrm{hr}$ in the case of wheat bran and for $8 \mathrm{hr}$ - in the case of soy flour. Wheat bran and soybean meal show the sorption capacity values of respectively $9.2 \cdot 10^{-3} \mathrm{~mol} \cdot \mathrm{kg}^{-1}$ and $8.4 \cdot 10^{-3} \mathrm{~mol} \cdot \mathrm{kg}^{-1}$ (sorption degrees are equal to $61 \%$ and $55 \%$ ). Fig. 10 shows the kinetic curves of copper ions sorption from aqueous $\mathrm{CuSO}_{4}$ solutions on cellulose, sawdust and flax fibres.

There are observed significant differences in the kinetics and thermodynamics of copper ions sorption on cellulose-containing materials. Equilibrium in the distribution of copper ions without stirring is set at $40 \mathrm{~min}$ for flax fibre, at $30 \mathrm{~min}$ for sawdust, and after $1 \mathrm{~h}$ - for cellulose. The obtained values of sorption capacity were $\left(\mathrm{mmol}^{\mathrm{kg}} \mathrm{kg}^{-1}\right)$ : for flax fibre -10.1 ; for sawdust -9.5; for cotton cellulose - 7.1. The observed differences in equilibrium and kinetic characteristics are related to the different ratio of crystalline and amorphous regions in their structure [51]. With the increase of the amorphous part of cellulose materials, the swelling rate and the amount of absorbed water increase; simultaneously increases the sorption capacity towards other hydrophilic compounds. This permits to explain the observed differences in the sorption of heavy metal ions. Swelling of cellulose-containing materials in water as compared with activated carbon and ion-exchange resin Lewatit S-100 is presented in Table 4.

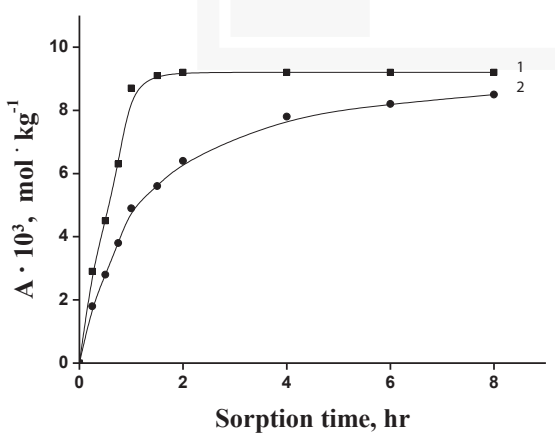

Fig. 9. The kinetics of $\mathrm{Zn}(\mathrm{II})$ sorption on wheat bran (1) and soy flour (2)

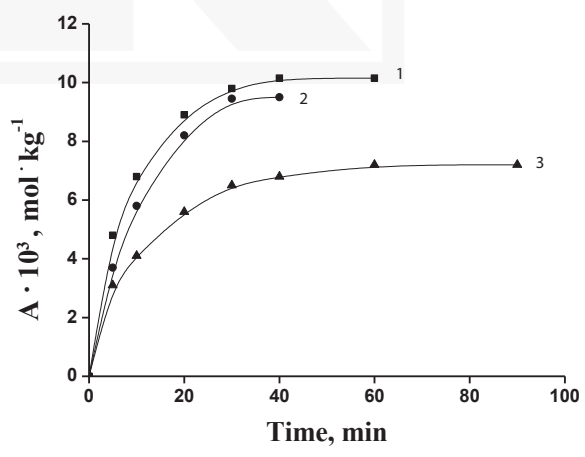

Fig. 10. Kinetic curves of $\mathrm{Cu}(\mathrm{II})$ sorption on short flax fibre (1), sawdust (2), cellulose (3) 
Table 4. Swelling of cellulose-containing materials in water

\begin{tabular}{|c|c|c|c|c|c|c|}
\hline Sorbent & $\begin{array}{c}\mathbf{A}^{*} \cdot \mathbf{1 0}^{3}, \\
\mathbf{m o l e} / \mathbf{k g}\end{array}$ & $\begin{array}{c}\tau_{\mathbf{e}^{\prime}} \\
\mathbf{m i n}\end{array}$ & $\begin{array}{c}\alpha, \\
\%\end{array}$ & $\begin{array}{c}\mathbf{A}_{\boldsymbol{\omega}^{\prime}} \\
\mathbf{m o l e} / \mathbf{k g}\end{array}$ & $\begin{array}{c}{[\mathbf{C O O H}],} \\
\mathbf{m o l e} / \mathbf{k g}\end{array}$ & $\begin{array}{c}\mathbf{X}, \\
\mathbf{g}_{\mathrm{H} 20} / \mathbf{g}_{\text {sorb }}\end{array}$ \\
\hline Cotton cellulose & 7.1 & 60 & 47 & 0.36 & 0.34 & 4.8 \\
\hline Sawdust & 9.5 & 30 & 63 & 0.43 & 0.46 & 5.7 \\
\hline Short flax fibre & 10.1 & 40 & 67 & 0.48 & 0.54 & 4.5 \\
\hline Artichoke stems & 13.7 & 20 & 91 & 0.71 & 0.82 & 10.2 \\
\hline Wheat bran & 9.2 & 120 & 61 & 0.41 & 0.21 & 2.6 \\
\hline Soybean meal & 12.2 & 360 & 81 & 0.68 & 0.31 & 3.0 \\
\hline Activated carbon & 14.6 & 15 & 97 & - & - & 2.9 \\
\hline Lewatit S-100 & 15 & 15 & 100 & 2.2 & {$\left[\mathrm{SO}_{3} \mathbf{H}\right] \mathbf{4 . 9}$} & 1.6 \\
\hline
\end{tabular}

$\mathrm{A}^{*}$ - is the sorption capacity of the sorbent at an initial concentration of $\mathrm{Cu}(\mathrm{II})$ in solution $1.5 \cdot 10^{-4} \mathrm{~mol} \cdot \mathrm{l}^{-1}$; X - swelling of the sorbents in water.

Sorption capacity values of the studied cellulose-containing materials with respect to copper ions decreased in a row: a short flax fibre $>$ sawdust $>$ cotton cellulose. This number is consistent with a decrease in the proportion of amorphous regions of cellulose in these sorbents. Thus, cellulosic materials capable of good swelling in aqueous solutions show better sorption characteristics due to the greater content of the amorphous regions in their structure.

To determine the rate-limiting step of the sorption process, the plot of the dependence of the degree of sorption process completeness $(\mathrm{F})$ versus time $(\tau)$ was received. As it shown in Fig. 11, a half-sorption period proceeds within $7 \mathrm{~min}$ for sawdust and $12 \mathrm{~min}-$ for flax. The initial linear section of the plot of $\mathrm{F}$ versus $\sqrt{\tau}$ (Fig. 12) suggests a significant contribution of intraparticle diffusion to the mechanism of $\mathrm{Cu}$ (II) sorption on sawdust and flax fibres.

Final conclusion on the rate-limiting step of the process of heavy metal ions sorption on polysaccharide sorbents was done on the base of kinetics study of $\mathrm{Zn}$ (II) sorption on sawdust with interruption sorbent - solution interfacial contact. It is known that the kinetic sorption curves are not the same in experiments with - and without interruption of phase contact in the case of intraparticle diffusion kinetics [47].

The experimental data plots of $\mathrm{F}$ versus time $(\tau)$ for $\mathrm{Zn}(\mathrm{II})$ sorption with interruption of interfacial contact $(\delta \tau)$ for $2 \mathrm{~h}$ and without phase separation indicated that the kinetic curves are not identical (Fig. 13). This indicates that the rate of $\mathrm{Zn}$ (II) sorption on sawdust is limited by diffusion of ions inside the polymer granules (intraparticle diffusion kinetics).

Kinetic experiments on heavy metal ions sorption on polysaccharide materials were also performed with shaking. It has been found that shaking does not affect the sorption capacity of tested materials at equilibrium, but it significantly impacts the equilibration time $\left(\tau_{\mathrm{e}}\right)$ in the heterophase system. In experiments with shaking $\tau_{\mathrm{e}}$ values decreased markedly and were 10 min for sawdust, $15 \mathrm{~min}$ for flax fibre, $30 \mathrm{~min}$ for cotton cellulose, $45 \mathrm{~min}$ for wheat bran and $1 \mathrm{~h}$ for soybean meal. 


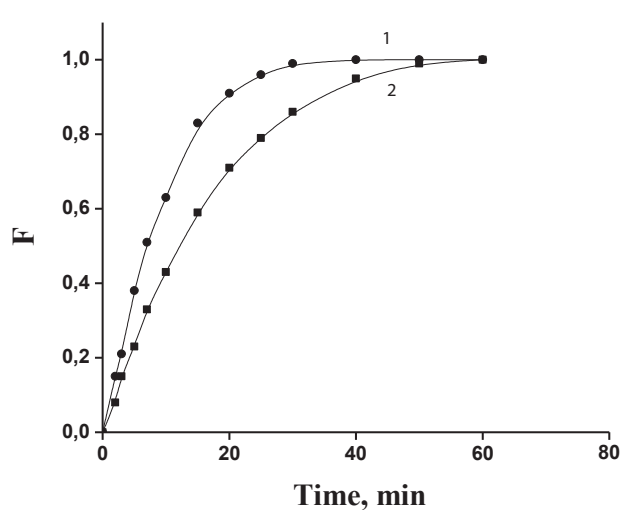

Fig. 11. Effect of contact time on degree of sorption process completeness for sawdust (1) and short flax fibres (2)

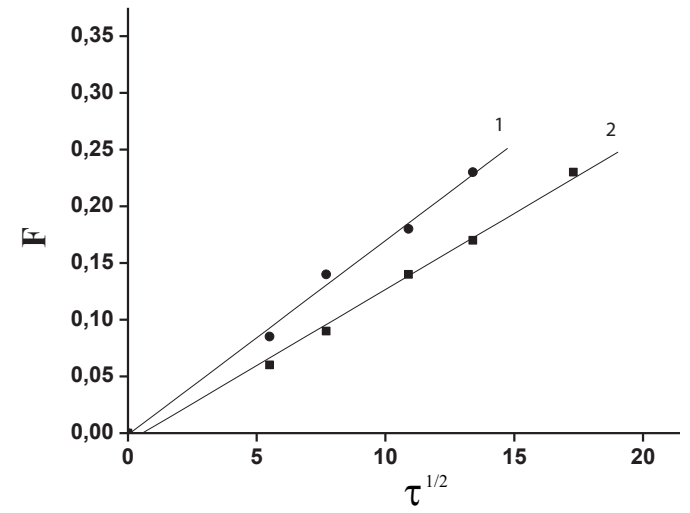

Fig. 12. Dependence of the degree of the process sorption completion with $\mathrm{t}^{1 / 2}$ for sawdust (1) and short flax fibres (2); $\mathrm{t}$ - is sorption time

The equilibrium time in the heterophase system "the polysaccharide sorbent - aqueous solution of metal salt" is also influenced by the treatment of biopolymer materials with alkaline solutions.

Cellulose and flax fibre were subjected for 30 min activation in $5 \% \mathrm{NaHCO}_{3}$ solution under boiling condition and in $0.05 \%$ solution of $\mathrm{NaOH}$ at room temperature, respectively. Figs 14 and 15 show the kinetic sorption curves of $\mathrm{Cu}$ (II) and $\mathrm{Ni}$ (II) on cotton cellulose treated with $\mathrm{NaHCO}_{3}$, and $\mathrm{Cu}$ (II) on artichoke stems, soybean meal and flax fibres treated with $\mathrm{NaOH}$.

As Fig. 14 shows, the equilibrium time in heterophase system "cotton cellulose - aqueous solution of the metal sulphate" is reduced to $10 \mathrm{~min}$ with the use of cellulose treated with $\mathrm{NaHCO}_{3}$, regardless of the metal nature.

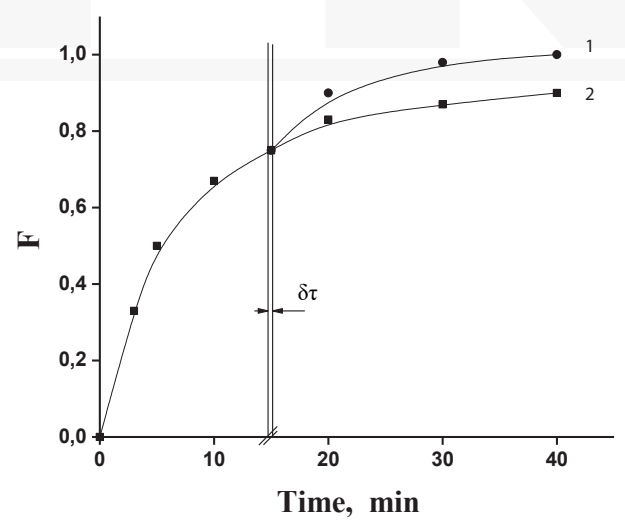

Fig. 13. Kinetic curves of $\mathrm{Zn}$ (II) sorption on sawdust with interruption (1) and without interruption (2) of interfacial contact; $(\delta \tau)$ was $2 \mathrm{~h}$ 
Sorption capacity of polysaccharide material is influenced by the metal nature. It is necessary also to note the effect of $\mathrm{NaHCO}_{3}$ solution treatment on the sorption capacity of cellulose. The sorption capacity of the cotton cellulose as a result of its treatment increases at $10 \%$.

As in the case of cellulose, the treatment of flax fibre with $\mathrm{NaOH}$ solution reduces the equilibrium time in heterophase system and increases the adsorption capacity of polysaccharide material.

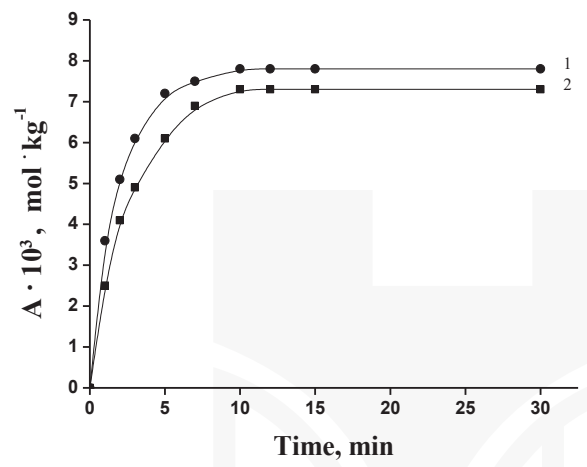

Fig. 14. Kinetic sorption curves of $\mathrm{Cu}(\mathrm{II})(1)$ and $\mathrm{Ni}(\mathrm{II})(2)$ on cotton cellulose treated with $\mathrm{NaHCO}_{3}$

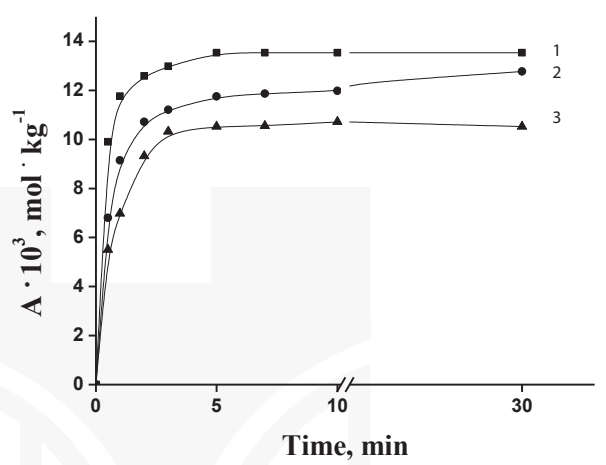

Fig. 15. Kinetic sorption curves of $\mathrm{Cu}(\mathrm{II})$ on artichoke stems (1), soybean meal (2) and flax fibres treated with $\mathrm{NaOH}(3)$ from aqueous solutions of copper sulphate

In order to determine the adsorption kinetics of $\mathrm{Cu}(\mathrm{II})$ ions, the first-order and secondorder kinetics models were checked [52]. Treatment of kinetic curves of $\mathrm{Cu}$ (II) sorption on soybean meal, artichoke stems and flax fibres using the kinetic models of pseudo-first and pseudo-second order is shown in Fig. 16 and 17.

The straight line of the plot of $\lg \left(C_{\mathrm{e}}-C_{\tau}\right)$ versus time (Fig. 16) suggests the applicability of the pseudo-first-order kinetics model for the present system. However, relatively low correlation coefficients: 0.95 for artichoke, 0.93 for flax and 0.91 for soybean meal were obtained in the treatment of kinetic curves.

As a result of the treatment of the kinetic sorption curves in the coordinates $t / C$ - time (Fig. 17) by the method of least squares performed using Origin, high correlation coefficients (0.999) for all polysaccharide materials were obtained.

\section{Conclusions}

Sorbents of plant origin on the base of cellulose represent undoubted practical and scientific interest from the point of view of their use in processes of heavy metal ions sorption from water solutions. They are characterised by the existence of a renewable base of raw materials, low cost especially in the case of agricultural waste. 


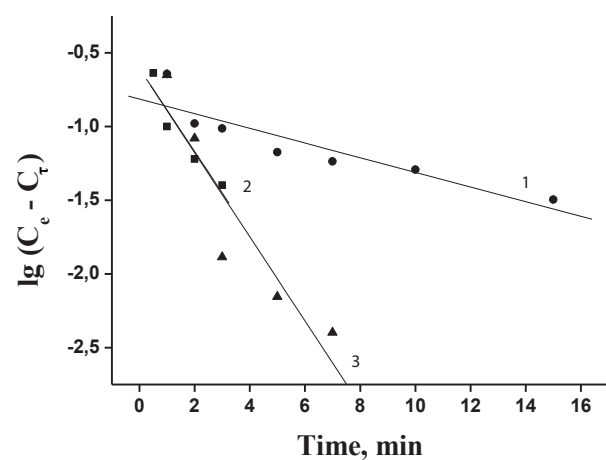

Fig. 16. Pseudo-first-order kinetic model of $\mathrm{Cu}$ (II) sorption on soybean meal (1), artichoke stems (2) and flax fibres (3)

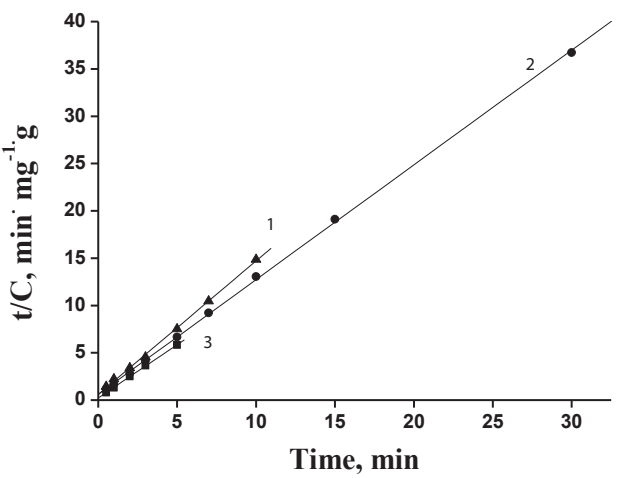

Fig. 17. Pseudo-second-order kinetic model of $\mathrm{Cu}$ (II) sorption on soybean meal (1), artichoke stems (2) and flax fibres (3)

Investigations of kinetics and thermodynamics of heavy metal ions distribution in the heterophase system "water solution - biopolymer" allow to optimise conditions of carrying out the sorption process in relation to a specific technological objective.

Analysis of the above presented literature data, and the data obtained in this study, permits to conclude that the kinetics of heavy metal ions sorption by polysaccharide absorbents is most correctly described by the pseudo - second order kinetics model.

This work was supported by The Russian Foundation for Basic Research, project 14-03-00417-a.

\section{References}

[1] Zhao G., W.X., Tan X., Wang X., Sorption of heavy metal ions from aqueous solutions: a review, The Open Colloid Sci J, Vol. 4, 2011, 19-31.

[2] Baral S.S., Das S.N., Rath P., Hexavalent chromium removal from aqueous solution by adsorption on treated sawdust, Biochem Eng J, Vol. 31, 2006, 216-222.

[3] Ho Y.S., Ng J.C.Y., McKay G., Pseudo-second order model for sorption processes, Process Biochemistry, Vol. 34(5), 1999, 451-465.

[4] Ho Y.S., Ng J.C.Y., McKay G., Kinetics of pollutant sorption by biosorbents: Review, Separation and Purification Methods, Vol. 29(2), 2000, 189-232.

[5] Aydin H., Bulut Y., Yerlikaya C., Removal of copper (II) from aqueous solution by adsorption onto low-cost adsorbents, J Environ Management, Vol. 87, 2008, 37-45.

[6] Sağ Y., Aktay Y., Mass transfer and equilibrium studies for the sorption of chromium ions onto chitin, Process Biochemistry, Vol. 36, 2000, 157-173. 
[7] Ho Y.S., Ng J.C.Y., McKay G., Second-order kinetic model for the sorption of cadmium onto tree fern: a comparison of linear and non-linear methods, Water Res, Vol. 40, 2006, 119125.

[8] Sharma R.K., Synthesis and characterization of graft copolymers of N-Vinyl-2-Pyrrolidone onto guar gum for sorption of $\mathrm{Fe}(\mathrm{II})$ and $\mathrm{Cr}$ (VI) ions, Carbohydrate Polymers, Vol. 83, 2011, 29-36.

[9] Ho Y.S., McKay G. Pseudo-second order model for sorption processes, Process Biochemistry, 34, 1999, 451-465.

[10] Farooq U., Kozinski J.A., Khan M.A., Athar M., Biosorption of heavy metal ions using wheat based biosorbents - A review of recent literature, Bioresource Technology, Vol. 101, 2010, 5043-5053.

[11] Ho Y.S., Ng J.C.Y., McKay G. Kinetics of pollutant sorption by biosorbents: review, Separ Purif Methods, Vol. 20(2), 2000, 189-232.

[12] Argun M.E., Dursun S., Ozdemir C., Karatas M., Heavy metal adsorption by oak sawdust: thermodynamics and kinetics, J Hazard Mater, Vol. 141, 2007, 77-85.

[13] Arshad M., Zafar M.N., Younis S., Nadeem R., The use of neem biomass for the biosorption of zinc from aqueous solutions, J Hazard Mater, Vol. 157, 2008, 534-540.

[14] Garg V.K., Gupta R., Kumar R., Gupta R.K., Adsorption of chromium from aqueous solution on treated sawdust, Bioresour Technol, Vol. 92(1), 2004, 79-81.

[15] Hanif M.A., Nadeem R., Zafar M.N., Aktar K., Bhatti H.N., Nikel (II) biosorption by Casia fistula biomass, J Hazard Mater, Vol. 139(2), 2007, 345-355.

[16] Saeed A., Akhter M.W., Iqbal M. Removal and recovery of heavy metals from aqueous solution using papaya wood as a new biosorbents, Sep Purif Technol, Vol. 45(1), 2005, 25-31.

[17] Min S.H., Han J.S., Shin E.W., Park J.K., Improvement of cadmium ion removal by base treated juniper fiber, Water Res, Vol. 38(5), 2004, 1289-1295.

[18] Chakravarty S., Pimple S., Hema S., Chaturvedi T., Singh S., Gupta K.K., Removal of copper from aqueous solution using newspaper pulp as an adsorbent, J Hazard Mater, Vol. 159(2), 2008, 396-403.

[19] Zheng L.S., Dang Z., Yi X.Y., Zhang H. Equilibrium and kinetic studies of adsorption of $\mathrm{Cd}$ (II) from aqueous solution using modified corn stalk, J Hazard Mater, Vol. 176(1-3), 2010, 650-656.

[20] Ghodbane I., Hamdaoui O., Removal of mercury (II) from aqueous media using eucalyptus bark: kinetic and equilibrium studies, J Hazard Mater, Vol. 160(2-3), 2008, 301-309.

[21] Ghodbane I., Nouri L., Hamdaoui O., Chiha M., Kinetic and equilibrium study for the sorption of cadmium (II) ions from aqueous phase by eucalyptus bark, J Hazard Mater, Vol. 152(1), 2007, 148-158.

[22] Lohani M.B., Singh A., Rupainwar D.C., Dhar D.N., Studies on efficiency of guava (Psidium guajava) bark as bioadsorbent for removal of $\mathrm{Hg}$ (II) from aqueous solutions, J Hazard Mater, Vol. 159(2-3), 2008, 626-629.

[23] King P., Srinivasa P., Kumar Y.P., Prasad V.S.K.R., Sorption of copper (II) ion from aqueous solution by Techtona grandis L.F. (teak leaves powder), J Hazard Mater, Vol. 136(3), 2006, 560-566. 
[24] Rao K.S., Anand S., Venkateswarlu P., Adsorption of cadmium (II) ions from aqueous solution by Tectona grandis L.F. (teak leaves powder), BioResources, Vol. 5(1), 2010, 438-454.

[25] Ngah W.S.W., Hanafiah M.A.K.M., Adsorption of copper on rubber (Hevea brasiliensis) leaf powder: kinetic, equilibrium and thermodynamic studies, Biochem Eng J, Vol. 39(3), 2008, 521-530.

[26] Ngah W.S.W., Hanafiah M.A.K.M., Biosorption of copper ions from dilute aqueous solutions on base treated rubber (Hevea brasiliensis) leaf powder: kinetics, isoterm, and biosorption mechanisms, J Environ Sci -China, Vol. 20(10), 2008, 1168-1176.

[27] Qaizer S., Saleem A.R., Ahmad M.M., Heavy metal uptake by agro based waste materials. Environ, Biotechnol, Vol. 10, 2007, 409-416.

[28] Malkoc E., Ni(II) removal from aqueous solutions using cone biomass of Thuia orientalis, J Hazard Mater, Vol. 137(2), 2006, 899-908.

[29] Bulut Y., Tez Z., Adsorption studies on ground shells of hazelnut and almond, J Hazard Mater, Vol. 149(1), 2007, 35-41.

[30] Malkoc E., Nuhoglu Y., Determination of kinetic and equilibrium parameters of the batch adsorption of $\mathrm{Cr}(\mathrm{VI})$ onto waste acorn Quercus ithaburensis, Chem Eng Processing, Vol. 46(10), 2007, 1020-1029.

[31] Ofomaja A.E., Ho Y.S., Effect of $p H$ on cadmium biosorption by coconut copra meal, J Hazard Mater, Vol. 139(2), 2007, 356-362.

[32] Parab H., Joshi S., Shenoy N., Lali A., Sarma U.S., Sudersanan M., Determination of kinetic and equilibrium parameters of the batch adsorption of $\mathrm{Co}(\mathrm{II}), \mathrm{Cr}(\mathrm{III})$ and $\mathrm{Ni}$ (II) onto coir pith, Process Biochem, Vol. 41(3), 2006, 609-615.

[33] Saeed A., Iqbal M., Holl W.H., Kinetics, equilibrium and mechanism of $\mathrm{Cd}^{2+}$ removal from aqueous solution by mungbean husk, J Hazard Mater, Vol. 168(2-3), 2009, 1467-1475.

[34] Altundogan H.S., Arslan N.E., Tumen F. Copper removal from aqueous solutions by sugar beet pulp treated by $\mathrm{NaOH}$ and citric acid, J Hazard Mater, Vol. 149(2), 2007, 432-439.

[35] Klemm D., Philipp B., Heinze D., Heinze U., Wagenknecht W., Comprehensive Cellulose Chemistry, Vol. 1: Fundamentals and Analytical Methods, Weinheim, Wiley-WCH, Germany 1998.

[36] Cellulose and Cellulose Derivatives, Eds: N.M. Bikales, L. Segal, Wiley, New York 1971.

[37] Bismark A., Aranberri-Askargorta I., Springer J., Surface Characterization of Flax, Hemp and Cellulose Fibers, Surface Properties and the Water Uptake Behavior, Polymer composites 2002, Vol. 23(5): 872-894.

[38] Bos, Harriëtte L., The potential of flax fibres as reinforcement for composite materials, Technische Universiteit Eindhoven, Eindhoven 2004.

[39] Shulga G., Betkers T., Shakels V., Neiberte B., Verovkins A., Brovkina J., Belous O., Ambrazaitene D., Žukauskaite A., Lignocellulosic mulch, polycomplex, soil, BioResources, Vol. 2(4), 2007, 572-582.

[40] Kays S.J., Nottingham S.E., Biology and chemistry of Jerusalem artichoke, Helianthus tuberosus L., CRC Press. Taylor \& Francis Group LLC, USA 2008. 
[41] Stevenson L., Phillips F., O'sullivan K., Walton J., Wheat bran: its composition and benefits to health, a European perspective, International Journal of Food Sciences and Nutrition, Vol. 63(8), 2012, 1001-1013.

[42] Karr-Lilienthal L.K., Grieshop C.M., Merchen N.R., Mahan D.C., Fahey G.C. Jr., Chemical composition and protein quality comparisons of soybeans and soybean meals from five leading soybean-producing countries, J Agric Food Chem, Vol. 52(20), 2004, 61936199.

[43] Sjöstrőm E., Alèn R., Analytical methods in wood chemistry, pulping and processing, Springer - Verlag Berlin Heidelberg, 1999.

[44] Nikiforova T.E., Kozlov V.A., A mechanism of extraction of heavy metal ions from aqueous solutions by chemically modified cellulose, Prot Met Phys Chem Surf, Vol. 48(6), 2012, 527-534.

[45] Kocherbitov V., Ulvenlund S., Kober M., Jarring K., Arnebrant T., Hydration of microcrystalline cellulose and milled cellulose studied by sorption calorimetry, J Phys Chem B, Vol. 112(12), 2008, 3728-3734.

[46] Krässig H.A., Cellulose: structure, accessibility and reactivity Polymer monographs, V. 11. 1993, Gordon and Breach Science Publishers.

[47] NikiforovaT.E., Kozlov V.A., Various factors affecting heavy metal ion sorption from aqueous media by sorbent containing cellulose, Prot Met Phys Chem Surf, Vol. 47(1), 2011, 20-24.

[48] Nikonorov V.V., Ivanov R.V., Kil'deeva N.R., Lozinskii V.I., Effect of polymer precursor molecular mass on the formation and properties of covalently cross-linked chitosan cryogels, Polymer Science Ser A, Vol. 53(12), 2011, 1150-1158.

[49] Albert A., Sergeant E., Ionization Constants of Acids and Bases, Wiley, New York 1962, $179 \mathrm{p}$.

[50] Stavitskaya S.S., Mironyuk T.I., Kartel' N.T., Strelko V.V., Sorption characteristics of "food fibers" in secondary products of processing of vegetable raw materials, Russian J Appl Chem,, Vol. 74(4), 2001, 592-595.

[51] Mann J., Modern methods of determining crystallinity in cellulose, Pure Appl Chem, 5(12), 1962, 91-106.

[52] Febrianto J., Kosasih A.N., Sunarso J., Ju Y.-H., Indraswati N., Ismadji S., Equilibrium and kinetic studies in adsorption of heavy metals using biosorbent: A summary of recent studies, J Hazard Mater, Vol. 162, 2009, 616-645. 


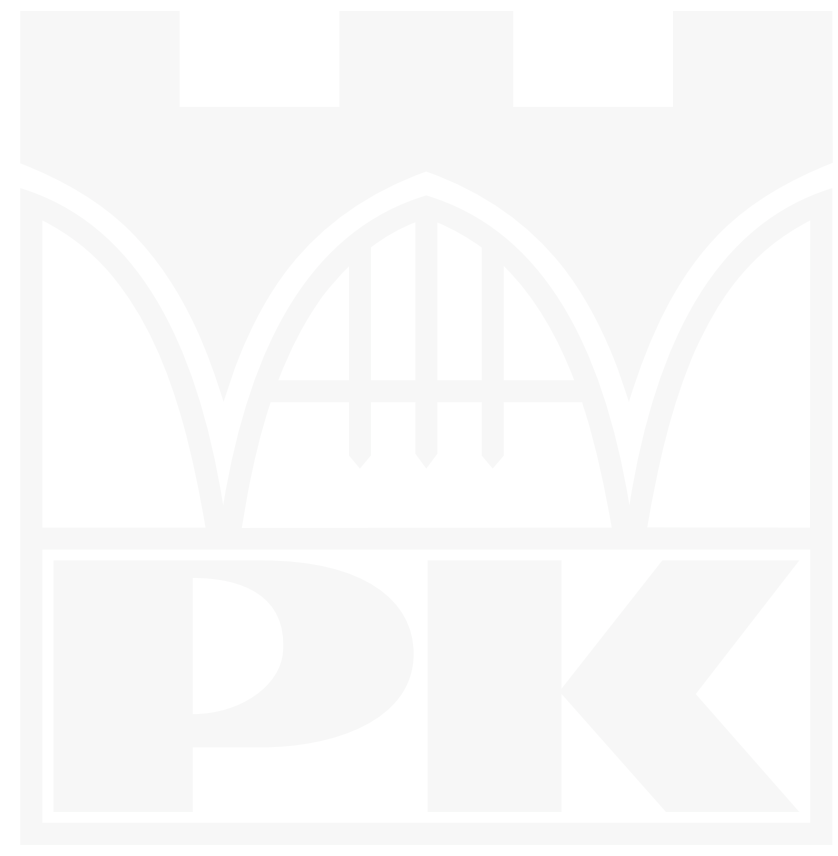

